\title{
Footing Design with Poured Earth
}

\author{
Carlos Zúñiga-Leal ${ }^{1}$, Edgardo J. Suárez-Domínguez ${ }^{1,2}$, Yolanda G. Aranda- \\ Jiménez ${ }^{1}$ \\ ${ }^{1}$ Facultad de Arquitectura. Universidad Autónoma de Tamaulipas. Circuito Interior S/N. Centro Universitario \\ Tampico-Madero. Tampico, Tam. México. \\ ${ }^{2}$ Centro de Investigación Aplicada y Tecnológica. Circuito Golfo de Mexico 200. Pórticos de Miramar. Cd \\ Madero, Tam. México.
}

\begin{abstract}
Nowadays, sustainable building is a responsibility within construction and the use of bearing walls made of compressed earth blocks, rammed earth, poured earth, among other earth building techniques, has become more frequent. Nevertheless, generally these structures must be found over foundations that correspond to the conventionally used reinforced concrete. Even though from a sustainable point of view, the use of stone is accepted, within the cases of zones where this material does not exist, it is necessary to develop new ecologic technologies compatible with the elements it sustains. This paper proposes the use of poured earth or fluid soilcement, of the south area of Tamaulipas, Mexico as a material for foundations; pointing out the use of designed footings that can be substituted by a monolithic piece with low steel quantity and proposing its constructive method based on stone structures.
\end{abstract}

Keywords : Poured earth, footing ecologic design, eco architecture.

\section{Introduction}

Nowadays, the use of sustainable materials has been proposed for the development of the dwelling [1] based on ancestral constructive systems [2]. Some of the examples are the rammed earth or the use of rods showing good acceptance in several countries [3]; It has been realized, from the Eco efficiency and carbon dioxide analysis, the use of earth based materials: in some countries like Iraq, the effects on the socioeconomical and environmental benefit that this type of feasible architecture proposes with the advantage of the use of elements present near the edifications [4]. Other benefits that have been found with this type of solutions are the visual effects and thermal comfort. [5]

On the architecture of the Bronze Age, the stone foundation was mainly used, attached with volcanic materials [6], though unfortunately this material is not available on most cases. Using existing elements of the region is generally advisable because it allows to reduce the social and environmental impact [7]

Even with the benefits that have been found, the world should adopt a development within this type of architecture [8] and the results found regarding the resistance of vertical structural elements in the building are encouraging [9] in many places the foundation continues to be a problem for the previously mentioned elements mainly because the earth elements, by themselves, have a low humidity resistance [10] that can be present in the subsoil and, even though it has been observed that the stone is a viable solution to this [11] as the rocky combinations with other elements [12] in many places there is no such alternative due to the transportation expenses it implies and the natural availability.

In the present work, the use of poured earth is proposed as a component of a foundation for which an analysis of the material and structure is presented as part of the design of these element such as isolated and continuous footing.

Poured earth is a fluid mix, recent term referring to a dosified mixture of gravel, sand and silt, agglomerated by clay. Doat, P., Hays, A., et. Al (1990). Poured earth is also considered a soil in liquid mud form, but containing sandy aggregates, even to a gravel point and can perform the same function as lean concrete Houben y Guillaud, (2005).

\section{Development of experiments}

\section{Method}

For the experiments a soil called Champayan was used, whose characteristics are placed on Table 1.

From such soil obtained in Altamira, Tamaulipas, mixtures were made with $6 \%$ of cement and water to obtain a fluid material that was poured into molds to obtain the cylinder of $15 \mathrm{~cm}$ of diameter and a height of $30 \mathrm{~cm}$ developing the mechanical resistance test to compression according to Mexican standard NMX-C083ONNCE-2002. 


\begin{tabular}{lcc}
\multicolumn{1}{c}{ Determination } & Champayan & Units \\
\hline Aparent Density & 1,78 & $(\mathrm{~g} / \mathrm{mL})$ \\
pH & 9,5 & upH \\
Conductivity & 0,22 & $\mathrm{mS} / \mathrm{cm}$ \\
Organic Mater & 1,8 & $\%$ \\
Humidity Content & 15,5 & $\%$ \\
Texture & & \\
Clay & 2,5 & $\%$ \\
Silt & 18,0 & $\%$ \\
Sand & 79,5 & $\%$
\end{tabular}

Table 1.- Soil characterization denominated Champayan in Altamira, Tam. Mexico-

The determination of flexural strength was made by similar specimens according to the standard NMX-C-191ONNCCE-2004. The adherence test was realized by immersion of rods in fresh cylinders allowing the mixture to dry and analyzing it after 28 .

\begin{tabular}{|l|c|c|c|c|}
\hline & $\begin{array}{c}\text { ARMED } \\
\text { FOOTING }\end{array}$ & $\begin{array}{c}\text { SOLID } \\
\text { FOOTING }\end{array}$ & $\begin{array}{c}\text { CONTINOUS } \\
\text { FOOTING }\end{array}$ & Units \\
\hline Last Load & $20.000,00$ & $20.000,00$ & $4.962,50$ & $\mathrm{~kg}$. \\
\hline Terrain resistance & 0,950 & 0,950 & 0,950 & $\mathrm{~kg} / \mathrm{cm}^{2}$. \\
\hline Soil volumetric weight & $1.800,00$ & $1.800,00$ & $1.800,00$ & $\mathrm{~kg} / \mathrm{m}^{3}$. \\
\hline Poured earth volumetric weight & $1.800,00$ & $1.800,00$ & $1.800,00$ & $\mathrm{~kg} / \mathrm{m}^{3}$. \\
\hline Layout depth & 1,10 & 1,10 & 1,10 & $\mathrm{~m}$. \\
\hline Column B Dimension & 25,00 & 25,00 & NA & $\mathrm{cm}$ \\
\hline Column H Dimension & 25,00 & 25,00 & NA & $\mathrm{cm}$ \\
\hline Wall Width & NA & NA & 20,00 & $\mathrm{~cm}$ \\
\hline f'c poured earth & 100,00 & 100,00 & 100.00 & $\mathrm{~kg} / \mathrm{cm}^{2}$ \\
\hline f*c equivalent & 80,00 & 80,00 & 80,00 & $\mathrm{~kg} / \mathrm{cm}^{2}$ \\
\hline f"c equivalent & 68,00 & 68,00 & 68,00 & $\mathrm{~kg} / \mathrm{cm}^{2}$ \\
\hline fy steel & $4.200,00$ & $4.200,00$ & $4.200,00$ & $\mathrm{kf} / \mathrm{cm}^{2}$. \\
\hline
\end{tabular}

Table 2.- Data used for the design of an armed footing, a solid footing and a continuous footing

\section{Results And Discussion}

The compression resistance of the element produced with poured earth was of $100 \pm 1 \mathrm{~kg} / \mathrm{cm} 2$. Of the tension resistance test a result of the $11,0 \pm 0,2 \mathrm{~kg} / \mathrm{cm} 2$ was obtained. Figure 1 shows the cylinders in molds prepared for this test.

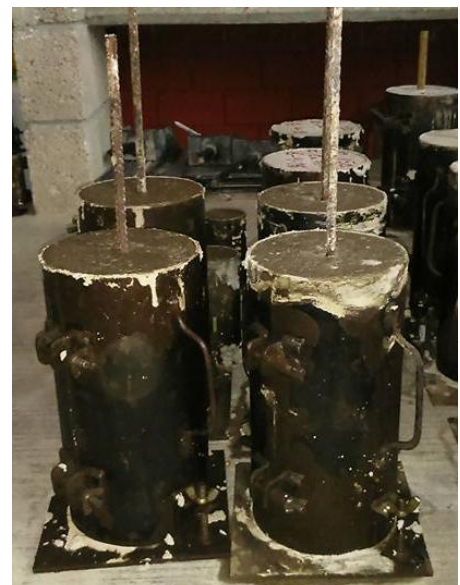

Figure 1.- Image of the poured earth cylinders used with a rod in the central part before demolding.

The volumetric weight of the material resulted in $1800 \pm 5 \mathrm{~kg} / \mathrm{cm} 2$.

Regarding the adherence test a value of $0,81 \pm 0.01$ was obtained for an effort of $158 \mathrm{~kg}$. that are visualized in Table 3. Noting that when using a disposition of a continuous footing the necessary camber to support the proposed compression effort is reduced considerably. All the design cases were developed considering a uniform pressure value smaller than the allowed to avoid efforts due to ground settlements.

Table 4 presents the design by penetration for the case of elements as isolated footing. It has been found that for the poured earth case the footing area should be broadened substantially and to support the penetration effort similar to the first one, increase a $100 \%$ the camber. 
SIZING

\begin{tabular}{|l|c|c|c|c|}
\hline \multicolumn{2}{|c}{ A } & B & C & Units \\
\hline Proposed total camber & 30,00 & 60,00 & 30,00 & $\mathrm{~cm}$. \\
\hline Effective camber & 24,00 & NA & NA & $\mathrm{cm}$. \\
\hline Filling depth & 0,800 & 0,50 & 0,80 & $\mathrm{~m}$. \\
\hline Filling pressure & 0,144 & 0,090 & 0,144 & $\mathrm{~kg} / \mathrm{cm} 2$. \\
\hline Own weight pressure & 0,054 & 0,108 & 0,054 & $\mathrm{~kg} / \mathrm{cm} 2$. \\
\hline Net resistance & 0,752 & 0,752 & 0,752 & $\mathrm{~kg} / \mathrm{cm} 2$. \\
\hline Minimum area & $26.595,74$ & $26.595,74$ & NA & $\mathrm{cm} 2$. \\
\hline Minimum side & 163,08 & 163.08 & 65,99 & $\mathrm{~cm} 2$. \\
\hline Proposed side & 170,00 & 170,00 & 70,00 & $\mathrm{~cm}$. \\
\hline Column pressure & 0,692 & 0,692 & $\mathrm{NA}$ & $\mathrm{kg} / \mathrm{cm} 2$. \\
\hline Wall pressure & NA & NA & 0,709 & $\mathrm{~kg} / \mathrm{cm} 2$. \\
\hline Total pressure over ground & $\mathbf{0 , 8 9 0}$ & $\mathbf{0 , 8 9 0}$ & $\mathbf{0 , 9 0 7}$ & $\mathbf{k g} / \mathrm{cm} 2$. \\
\hline
\end{tabular}

Table 3.- Results of the sizing of the footing for the three analyzed cases A) poured earth footing with reinforcing steel, B) simple isolated footing with poured earth and C) continuous footing with poured earth.

PENETRATION DESIGN

\begin{tabular}{|l|c|c|c|}
\hline \multicolumn{2}{|c|}{ A } & B & Units \\
\hline Critical side & 49,00 & 85,00 & $\mathrm{~cm}$. \\
\hline Critical perimeter & 196,00 & 340,00 & $\mathrm{~cm}$. \\
\hline Critical area & $4.704,00$ & $20.400,00$ & $\mathrm{~cm} 2$. \\
\hline Penetration force & $23.585,21$ & $19.291,65$ & $\mathrm{~kg}$. \\
\hline Penetration effort & 5,01 & 0,95 & $\mathrm{~kg} / \mathrm{cm} 2$. \\
\hline Admissible penetration effort & 7,16 & 7,16 & $\mathrm{~kg} / \mathrm{cm} 2$. \\
\hline
\end{tabular}

Table 4.- Results obtained from the penetration design for the isolated footing case of a) an element con design of poured earth with reinforcing steel, b) an isolated footing with poured earth.

Table 5 presents the results obtained for the flexion element design.

FLEXION DESIGN

\begin{tabular}{|l|c|c|c|l|}
\hline \multicolumn{2}{|c}{ A } & \multicolumn{2}{c|}{ C Unit } & $\mathrm{cm}$. \\
\hline Flexion length & 72,50 & 72,50 & 25,00 & $\mathrm{c}$ \\
\hline Design momentum & $233.914,04$ & $233.914,04$ & $28.341,52$ & $\mathrm{~kg}-\mathrm{cm}$. \\
\hline Minimum reinforcement percentage & 0,167 & $\mathrm{NA}$ & --- & $\%(\mathrm{~A} / \mathrm{A})$ \\
\hline Inertia section & --- & $1,800 \mathrm{E}+06$ & $225.000,00$ & $\mathrm{~cm} 4$. \\
\hline Value and & --- & 30,00 & 15 & $\mathrm{~cm}$ \\
\hline Maximum tension effort & --- & 3,899 & 1,889 & $\mathrm{~kg} / \mathrm{cm} 2$. \\
\hline Admissible tension effort & --- & 8,800 & 8,8 & $\mathrm{~kg} / \mathrm{cm} 2$. \\
\hline Reinforcement percentage & 0,200 & --- & --- & \\
\hline Reinforcement indication & 0,12353 & --- & --- & \\
\hline Resilient momentum & $408.560,19$ & --- & --- & $\mathrm{kg}-\mathrm{cm}$. \\
\hline Mr/Mdis & 1,72 & --- & --- & \\
\hline Temperature steel & --- & 18,00 & 6,30 & $\mathrm{~cm} 2$. \\
\hline Number of beds & --- & 3,00 & 1,00 & \\
\hline Steel by bed & --- & 6,00 & 6,30 & $\mathrm{~cm}$ \\
\hline Steel area & 4,80 & --- & --- & \\
\hline Rod number & 3,00 & 4,00 & 4,00 & \\
\hline Separation & 14,84 & 21,11 & 15,00 & $\mathrm{~cm}$. \\
\hline
\end{tabular}

Table 5- Flexion design for the three selected cases A) a poured earth footing with reinforcing steel, B) simple isolated footing with poured earth and C) continuous footing with poured earth.

DESIGN SHEAR

\begin{tabular}{|l|c|c|c|c|}
\hline & \multicolumn{2}{c}{ A } & C & Unit \\
\hline Section length & 61,00 & 25,00 & 25,00 & $\mathrm{~cm}$. \\
\hline Section length $(\mathrm{Vu})$ & $5.429,25$ & $2.225,10$ & $2.267,32$ & $\mathrm{~kg}$. \\
\hline Section plane momentum & $165.592,23$ & $27.813,80$ & --- & $\mathrm{Kg}-\mathrm{cm}$. \\
\hline $\mathrm{A}<4 \mathrm{~d}$ & 96 & 240,00 & --- & $\mathrm{cm}$. \\
\hline $\mathrm{h}<60$ & 30 & 60 & --- & $\mathrm{cm}$. \\
\hline $\mathrm{M} / \mathrm{Vd}<2$ & 1,27 & 0,21 & --- & --- \\
\hline Section resisting force $(\mathrm{Vcr})$ & 8.586 .50 & $21.466,25$ & $10.733,13$ & $\mathrm{Kg}$. \\
\hline Conclusions & Section ok & Section ok & Section ok & \\
\hline
\end{tabular}

Table 6.- Design shear for the three studied cases 
Regarding an isolated monolithic footing, when realizing a structure analysis using only poured earth in its composition, without using reinforcing steel by flexion, the camber dimension elevates to twice the armed element, due to the tension efforts generated by the flexion in the element are solely supported by the poured earth. It is evident that the volume of material used duplicates, nonetheless the cost of this material is minimal compared to steel that must be included but only temperature steel which could be reduced by adding other materials such as natural fibers.

From the analysis as to how a continuous poured earth footing, made with poured earth for usual loads in a one level dwelling, without reinforcing flexion steel, the efforts generated by the loads will be absorbed completely only by the solid, for which the total camber is conditioned to maintain a low tension effort in such material. Due to the length dimension, is necessary to absorb the efforts by volumetric chance, for which it is proposed the addition of steel, known as temperature, to the extent of substituting it for a resistant fiber such as plastic, "ixtle" or steel slag. The objective is to absorb all the resulting tensions to reduce cracking.

\section{Conclusion}

The development of a poured earth structure is proposed as part of the foundation of a structure.

From the theoretical analysis and the results on a laboratory basis regarding the compression resistance, it has been found that resistances up to $100 \mathrm{~kg} / \mathrm{cm} 2$ can present themselves with doses of $15 \%$, which would mean a linear relation regarding the design of a concrete structure, however, the adherence found in a rebar was 90\% less than the obtained with concrete but similar to the adherence to a smooth rod with concrete.

Considering solely the compression resistance of the analyzed element, a sizing directly proportional to a similar with simple concrete is obtained.

Nonetheless, it must be taken into account that the adherence of concrete is different to the one found in a conventional material, which is mitigated by the camber increase in the foundation, in a way that, as poured earth mainly has a compression resistance, a monolithic element inside the surface can be made.

In future work it will be necessary to make a study substituting steel for natural fibers that support the efforts due to temperature.

\section{Acknowledgements}

The authors would like to thank Pedro Becerra for the support in the operation during the laboratory tests.

\section{References}

[1] Samani, P., Mendes, A., Leal, V., Guedes, J. M., \& Correia, N. (2015). A sustainability assessment of advanced materials for novel housing solutions. Building and Environment, 92, 182-191.

[2] Akinwumi, I. I., Awoyera, P. O., \& Bello, O. O. (2015). Indigenous earth building construction technology in Ota, Nigeria. Indian Journal of Traditional Knowledge, 14(2), 206-212.

[3] Kailey, A., \& Gupta, R. (2016). Current State of Modern Rammed Construction: A Case Study of First Peoples House after Seven Years Exposure. Key Engineering Materials, 666.

[4] Ferrández-García, A., Ibáñez-Forés, V., \& Bovea, M. D. (2016). Eco-efficiency analysis of the life cycle of interior partition walls: a comparison of alternative solutions. Journal of Cleaner Production, 112, 649-665.

[5] Samani, P., Leal, V., Mendes, A., \& Correia, N. (2016). Comparison of passive cooling techniques in improving thermal comfort of occupants of a pre-fabricated building. Energy and Buildings, 120, 30-44.

[6] Kormann, M., Katsarou, S., Katsonopoulou, D., \& Lock, G. (2015). Structural Integrity Modelling of an Early Bronze Age Corridor House in Helike of Achaea, NW Peloponnese, Greece. CAA 2015 Siena.

[7] Mendonça, P., \& Martins, B. (2015). Environmental impact reduction from using local natural construction materials: Case study in the North of Portugal. International Journal of Environmental Science and Development, 6(11), 833-837.

[8] Folke, C., Carpenter, S., Elmqvist, T., Gunderson, L., Holling, C. S., \& Walker, B. (2002). Resilience and sustainable development: building adaptive capacity in a world of transformations. AMBIO: A journal of the human environment, 31(5), 437-440.

[9] Miccoli, L., Müller, U., \& Fontana, P. (2014). Mechanical behaviour of earthen materials: a comparison between earth block masonry, rammed earth and cob. Construction and Building Materials, 61, 327-339

[10] Schroeder, H. (2016). Demolition, Recycling, and Disposal of Earth Building Materials. In Sustainable Building with Earth (pp. 505-526). Springer International Publishing.

[11] Sedláková, A., Vilčeková, S., \& Burdová, E. K. (2015). Analysis of material solutions for design of construction details of foundation, wall and floor for energy and environmental impacts. Clean Technologies and Environmental Policy, 17(5), 1323-1332.

[12] Luo, J., Wang, X., \& Luo, J. Earth as a building material for reproduction of ancient buildings in China Meishan cultural park. 